\title{
Pemodelan dengan Spatial Autoregressive (SAR) pada Angka Putus Sekolah Bagi Anak Usia Wajib Belajar di Provinsi Sulawesi Selatan
}

\author{
Rika Nasir*, Suwardi Annas, \& Muhammad Nusrang
}

Program Studi Statistika, Fakultas Matematika dan Ilmu Pengetahuan Alam, Universitas Negeri Makassar, Indonesia

Keywords: Regresi Spasial, Spatial Autoregressive Model (SAR), Angka Putus Sekolah

\begin{abstract}
:
Regresi spasial merupakan pengembangan dari regresi klasik. Pengembangan ini berdasarkan adanya pengaruh tempat atau spasial dari data yang dianalisis. Beberapa model regresi spasial adalah Spatial Autoregressive (SAR), Spatial Error Model (SEM) dan Spatial Moving Average (SARMA). Penelitian ini menggunakan analisis model SAR terhadap angka putus sekolah di Sulawesi Selatan. Data yang digunakan merupakan data sekunder dari Badan Pusat Statistik Provinsi Sulawesi Selatan tahun 2018. Penelitian ini dilakukan untuk mengetahui model Spatial Autoregressive (SAR) pada data banyaknya angka putus sekolah yang terjadi di Provinsi Sulawesi Selatan, serta mengenalisis faktor-faktor yang memberikan pengaruh signifikan terhadap pertumbuhan angka putus sekolah. Hasil penelitian ini memperoleh model yaitu $y_{i j}=0,4 \sum_{j=1, i=1}^{24} W_{i j} y_{i}+1491,2 X_{2}-64,8 X_{4}+2137,2 X_{5}$; sehingga faktor-faktor yang berpengaruh secara signifikan terhadap angka putus sekolah di Sulawesi Selatan adalah pengeluaran per kapita, rasio murid terhadap sekolah dan jumlah penduduk miskin.
\end{abstract}

\section{Pendahuluan}

Analisis regresi merupakan salah satu cabang dari ilmu statistika yang sering digunakan dalam menyelesaikan suatu masalah. Analisis regresi adalah suatu metode yang digunakan untuk menganalisis hubungan antara variabel respon dengan beberapa variabel prediktor (Simarmata dan Ispriyanti, 2010) dalam (Ruliana, 2015). Suatu analisis pemodelan regresi untuk mengetahui faktor-faktor yang mempengaruhi persentase suatu kejadian yang dipengaruhi oleh karakteristik wilayah sangat penting. Pengamatan di wilayah tertentu dipengaruhi oleh pengamatan di wilayah lain. Adanya efek spasial merupakan hal yang lazim terjadi antara satu wilayah dengan wilayah yang lain. Pada beberapa kasus, variabel respon yang diamati memiliki keterkaitan dengan hasil pengamatan di wilayah yang berbeda, terutama wilayah yang berdekatan. Untuk mengatasi permasalahan tersebut diperlukan suatu model regresi yang memasukkan hubungan spasial antar wilayah ke dalam model, sehingga model yang digunakan adalah model regresi spasial (Arisanti, 2011).

Sulawesi Selatan merupakan salah satu provinsi yang ada di Indonesia. Melihat dari sisi pengeluaran konsumsi masyarakat Sulawesi Selatan, mayoritas penduduk umur 7-12 tahun dari kalangan masyarakat miskin sampai kaya, sedang bersekolah. Namun beranjak pada kelompok usia selanjutnya (13-15 dan 16-18 tahun), penduduk pada kelompok pengeluaran terendah semakin menunjukkan bahwa banyak dari mereka mengalami putus sekolah. Pada tahun 2018, tercatat angka partisipasi sekolah untuk penduduk usia SD dan SLTP yaitu usia 7-12 tahun dan 13-15 tahun dengan nilai diatas 95\%, sedangkan untuk jenjang SMA/SMK yaitu usia 16-18 tahun hanya sekitar 71\% (Statistik, 2018). Hal ini menunjukkan bahwa pemerataan pendidikan di Sulawesi Selatan belum terealisasikan

\footnotetext{
* Corresponding author.

E-mail address: rikanasir99@gmail.com
} 
dengan baik, karena partisipasi sekolah belum mencapai 100\%. Secara garis besar, masih rendahnya angka partisipasi sekolah menunjukkan bahwa masalah putus sekolah dalam pengembangan pendidikan masih belum tuntas.

Banyaknya anak putus sekolah di suatu daerah sangat mungkin dipengaruhi oleh lingkungan atau kondisi geografis daerahnya, termasuk posisinya terhadap daerah lain. Regresi spasial dapat digunakan untuk menentukan dan menganalisis model anak tidak bersekolah di suatu lokasi, yang dikaji dari sisi pengaruh antara lokasi lain disekitarnya. Di dalam suatu observasi yang mengandung informasi ruang atau spasial, maka analisis data tidak akan akurat jika hanya menggunakan analisis regresi sederhana (Anselin, 1988). Putus sekolah merupakan salah satu indikator yang berguna untuk mengukur kemajuan sumber daya manusia pada bidang pendidikan.

Oleh karena itu, masalah anak putus sekolah tersebut perlu mendapatkan perhatian. Untuk menekan laju pertumbuhan jumlah anak putus sekolah dapat dilakukan dengan cara mengetahui faktor-faktor yang berpotensi memberikan sumbangsih terhadap pertumbuhan jumlah anak putus sekolah. Oleh kerena itu, peneliti tertarik untuk mengkaji faktor-faktor yang mempengaruhi banyaknya kasus putus sekolah usia wajib belajar di Provinsi Sulawesi Selatan. Sehingga variabel respon yang digunakan yaitu jumlah angka putus sekolah pada usia wajib belajar di Provinsi Sulawesi Selatan tahun 2018 dan variabel prediktor yang digunakan yaitu rata-rata lama sekolah, pengeluaran perkapita, jumlah penduduk miskin, rasio murid dan guru, rasio murid dan sekolah di Provinsi Sulawesi Selatan tahun 2018.

\section{Tinjauan Pustaka}

\subsection{Model Regresi Klasik}

Analisis regresi merupakan alat statistik yang banyak digunakan dalam berbagai bidang. Analisis tersebut bertujuan untuk mengetahui hubungan antara variabel respon dan variabel prediktor.

Persamaan regresi berganda adalah persamaan regresi dengan satu variabel respon $(Y)$ dengan lebih dari satu variabel prediktor $X_{1}, X_{2}, \ldots, X_{n}$ Hubungan antara variabel tersebut dapat dirumuskan dalam bentuk model:

$$
Y=\beta_{0}+\beta_{1} X_{1}+\beta_{2} X_{2}+\cdots+\beta_{n} X_{n}+\varepsilon
$$

Keterangan:

$$
\begin{array}{ll}
Y & =\text { Variabel respon (nilai yang diprediksikan) } \\
X_{1}, X_{2}, \ldots, X_{n} & =\text { Variabel prediktor } \\
\beta_{0} & =\text { Konstanta (nilai } Y \text { ' apabila }\left(X_{1}, X_{2}, X_{3}, \cdots, n=0\right) \\
\beta_{1} & =\text { Koefisien regresi (nilai peningkatan ataupun penurunan) } \\
\varepsilon & =\text { Error }
\end{array}
$$

Dimana $\beta_{0}$ merupakan konstanta dan $\beta_{n}$ merupakan koefisien regresi variabel prediktor ke $n$. Bila dituliskan dalam bentuk matriks:

$$
\boldsymbol{y}=\boldsymbol{X} \boldsymbol{\beta}+\varepsilon
$$

dimana:

$$
\begin{aligned}
& \boldsymbol{y}=\text { vektor berukuran } n \times 1 \\
& \boldsymbol{X}=\text { matriks berukuran } n \times(p+1) \\
& \boldsymbol{\beta}=\text { vektor berukuran }(p+1) \times 1 \\
& \boldsymbol{\varepsilon}=\text { vektor berukuran } n \times 1
\end{aligned}
$$

(Kurniawan, 2008).

\subsection{Matriks Pembobot}

Matriks pembobot spasial dapat digunakan untuk mengetahui kedekatan antar data spasial atau hubungan data spasial. Matriks pembobot spasial ini digunakan untuk menghitung koefisien autokorelasi yang terjadi pada daerah yang diamati. Matriks pembobot spasial terdiri dari entri-entri yang merupakan nilai pembobot yang diberikan untuk 
perbandingan antar daerah yang diamati. Matriks pembobot spasial merupakan hal yang sangat penting dalam analisis spasial yang menyatakan hubungan dari wilayah pengamatan yang berukuran $n \times n$ dan disimbolkan dengan $\boldsymbol{W}$. Matriks pembobot spasial digunakan untuk menentukan bobot antar lokasi yang diamati berdasarkan hubungan ketetanggaan antar lokasi.

\subsection{Uji Ketergantungan Spasial}

Uji Lagrange Multiplier ( $L M$ test) digunakan sebagai dasar untuk memilih model regresi spasial yang sesuai (LeSage, 2009). Uji yang digunakan untuk mengetahui model pengaruh spasial dalam data adalah menggunakan uji Lagrange Multiplier. Pengujian hipotesis Lagrange Multiplier adalah:

a. Regresi Spatial Autoregressive (SAR)

Hipotesis untuk model SAR adalah sebagai berikut:

$\mathrm{H}_{0}: \rho=0$ (tidak ada ketergantungan spasial lag)

$\mathrm{H}_{1}: \rho \neq 0$ (ada ketergantungan spasial lag)

Statistik $L M$ yang digunakan untuk Model Spatial Autoregressive (SAR) adalah sebagai berikut:

$$
L M_{L A G}=\frac{\left(\frac{e^{T} W y}{\sigma^{2}}\right)^{2}}{D} \sim X_{(\alpha, 1)}
$$

\section{b. Spatial Error Model (SEM)}

Hipotesis untuk model SEM adalah sebagai berikut:

$\mathrm{H}_{0}:=0$ (tidak ada ketergantungan spasial dalam error)

$\mathrm{H}_{1}: \neq 0$ (ada ketergantungan spasial dalam error)

Statistik LM yang digunakan untuk Regresi Spatial error Model (SEM) adalah sebagai berikut:

$$
L M_{E R R}=\frac{\left(\frac{e^{\prime} W e}{\hat{\sigma}^{2}}\right)^{2}}{T} \sim X_{(\alpha, 1)}
$$

Keputusan tolak $H_{0}$ dilakukan jika nilai $p$-value lebih kecil dari taraf nyata $\alpha$ (Anselin, 1988)

\subsection{Regresi Spasial}

Regresi spasial adalah analisis yang mengevaluasi hubungan antara satu variabel dengan beberapa variabel lain dengan memberikan efek spasial pada beberapa lokasi yang menjadi pusat pengamatan. Menurut (Anselin, 1988) bentuk umum model regresi spasial adalah sebagai berikut:

$$
\boldsymbol{y}=\rho \boldsymbol{W} y+\boldsymbol{X} \boldsymbol{\beta}+\boldsymbol{u}, \quad \boldsymbol{u}=\lambda \boldsymbol{W} \boldsymbol{u}+\varepsilon, \quad \boldsymbol{\varepsilon} \sim \mathrm{N}\left(0, \sigma^{2} \mathbf{I}\right)
$$

dengan $\boldsymbol{y}$ adalah vektor variabel respon berukuran $\mathrm{n} \times 1, \boldsymbol{X}$ adalah matriks variabel prediktor berukuran $\mathrm{n} \times(\mathrm{p}+1), \boldsymbol{\beta}$ adalah vektor koefisien parameter regresi berukuran $(\mathrm{p}+1) \times 1, \boldsymbol{W}$ adalah matriks pembobot spasial berukuran $\mathrm{n} \times \mathrm{n}, \boldsymbol{u}$ adalah vektor galat yang diasumsikan mengandung autokorelasi berukuran $\mathrm{n} \times 1, \boldsymbol{\varepsilon}$ adalah vektor galat yang bebas autokorelasi berukuran $\mathrm{n} \times 1, \rho$ adalah koefisien autoregresi lag spasial, $\lambda$ adalah koefisien autoregresi galat spasial, dan $\boldsymbol{I}$ adalah matriks identitas berukuran $\mathrm{n} \times \mathrm{n}$.

\subsection{Model Spatial Autoregressive (SAR)}

Model Spatial Autoregressive (SAR) atau Spatial Lag Model (SLM) adalah model yang mengkombinasikan model regresi linear dengan lag spasial pada variabel respon dengan menggunakan data cross section (Anselin, 1988). Spasial lag muncul saat nilai observasi variabel respon pada suatu lokasi berkorelasi dengan nilai observasi variabel respon di lokasi sekitarnya atau dengan kata lain terdapat korelasi spasial antar variabel respon. Pada model ini 
terdapat fungsi dari variabel respon pada lokasi $j$ yang digunakan sebagai variabel prediktor untuk memprediksi nilai dari variabel respon pada lokasi $i$.

Model SAR merupakan model regresi linear yang pada peubah responnya terdapat korelasi spasial (Anselin 1998). Model umum untuk SAR adalah sebagai berikut:

$$
\begin{aligned}
& \boldsymbol{y}=\rho \boldsymbol{W} y+\boldsymbol{X} \boldsymbol{\beta}+\boldsymbol{\varepsilon} \\
& \boldsymbol{\varepsilon} \sim N\left(0, \sigma^{2} \boldsymbol{I}\right)
\end{aligned}
$$

Parameter lag spasial $(\rho)$ menunjukkan tingkat korelasi pengaruh spasial dari suatu wilayah terhadap wilayah lain di sekitarnya (Ward \& Kristiani 2008) dalam (Arif, 2018).

\subsection{Putus Sekolah}

Putus sekolah adalah mereka yang pernah duduk pada salah satu tingkat pendidikan, akan tetapi pada saat survei berlangsung mereka tidak terdaftar pada salah satu pendidikan formal yang disebabkan oleh berbagai faktor. Angka putus sekolah mencerminkan presentasi anak-anak usia sekolah yang sudah tidak lagi bersekolah/tidak menamatkan jenjang pendidikan tertentu (Riyadi, dkk., 2015) dalam (Nasra, 2016). Program wajib belajar 12 tahun didasari konsep "pendidikan dasar untuk semua", yang hakekatnya berarti penyediaan akses terhadap pendidikan yang sama untuk semua anak. Melalui program wajib belajar, diharapkan dapat mengembangkan sikap, pengetahuan, dan keterampilan dasar yang perlu dimiliki semua warga negara sebagai bekal untuk dapat hidup layak di masyarakat.

\section{Metode Penelitian}

\subsection{Sumber Data}

Jenis data yang digunakan dalam penelitian ini adalah data sekunder yang dipublikasikan oleh Badan Pusat Statistik (BPS) Provinsi Sulawesi Selatan yaitu data angka putus sekolah, rata-rata lama sekolah, pengeluaran perkapita, rasio murid terhadap guru, rasio murid terhadap sekolah, dan jumlah penduduk miskin setiap Kabupaten di Provinsi

\begin{tabular}{|c|c|c|c|}
\hline Peubah & Nama Peubah & Jenis & Deskriptif \\
\hline $\mathrm{Y}$ & Putus Sekolah & Kontinu & $\begin{array}{l}\text { Jumlah angka putus sekolah pada usia wajib belajar di } \\
\text { setiap Kabupaten di Provinsi Sulawei Selatan, yaitu } \\
\text { penduduk usia } 7-18 \text { tahun. }\end{array}$ \\
\hline $\mathrm{X}_{1}$ & $\begin{array}{l}\text { Rata-rata Lama } \\
\text { Sekolah }\end{array}$ & Kontinu & $\begin{array}{l}\text { Tingkat pencapaian setiap penduduk dalam kegiatan } \\
\text { bersekolah di setiap Kabupaten di Provinsi Sulawei Selatan } \\
\text { pada tahun } 2018 \text {. }\end{array}$ \\
\hline $\mathrm{X}_{2}$ & $\begin{array}{l}\text { Pengeluaran per } \\
\text { Kapita }\end{array}$ & Kontinu & $\begin{array}{l}\text { Biaya yang dikeluarkan untuk konsumsi semua anggota } \\
\text { rumah tangga selama sebulan dibagi dengan banyaknya } \\
\text { anggota rumah tangga di setiap Kabupaten di Provinsi } \\
\text { Sulawesi Selatan pada tahun } 2018 \text {. }\end{array}$ \\
\hline$X_{3}$ & $\begin{array}{l}\text { Rasio Murid dan } \\
\text { Guru }\end{array}$ & Kontinu & $\begin{array}{l}\text { Perbandingan antara jumlah siswa dengan jumlah guru di } \\
\text { setiap Kabupaten di Provinsi Sulawei Selatan pada tahun } \\
2018 \text {. }\end{array}$ \\
\hline $\mathrm{X}_{4}$ & $\begin{array}{l}\text { Rasio Murid dan } \\
\text { Sekolah }\end{array}$ & Kontinu & $\begin{array}{l}\text { Perbandingan antara jumlah siswa dengan jumlah sekolah } \\
\text { di setiap Kabupaten di Provinsi Sulawei Selatan pada tahun } \\
2018 \text {. }\end{array}$ \\
\hline $\mathrm{X}_{5}$ & $\begin{array}{c}\text { Jumlah Penduduk } \\
\text { Miskin }\end{array}$ & Kontinu & $\begin{array}{l}\text { Penduduk dengan kondisi kehidupan serba kekurangan } \\
\text { sehingga tidak mampu memenuhi kehidupan yang layak } \\
\text { bagi kehidupannya di setiap Kabupaten di Provinsi Sulawei } \\
\text { Selatan pada tahun } 2018 \text {. }\end{array}$ \\
\hline
\end{tabular}
Sulawesi Selatan pada tahun 2018. 


\subsection{Teknik Analisis}

Pengelolaan data dilakukan dengan urutan sebagai berikut:

1) Melakukan pemodelan regresi klasik

2) Menentukan pembobot spasial ( $\boldsymbol{W}$ ) yaitu Queen contiguity.

3) Uji Ketergantungan spasial dengan Lagrange Multiplier untuk mendeteksi dependensi spasial dengan lebih spesifik yaitu dengan dependensi dalam lag, error, atau keduanya (lag dan error).

4) Melakukan pemodelan regresi Spatial Autoregressive (SAR).

5) Interpretasi hasil.

\section{Hasil dan Pembahasan}

\subsection{Model Regresi Klasik}

Pemodelan regresi klasik digunakan untuk mengetahui hubungan variabel-variabel prediktor terhadap angka putus sekolah. Tabel 1 menyajikan hasil pengujian model regresi klasik untuk angka putus sekolah anak usia wajib belajar di Provinsi Sulawesi Selatan tahun 2018.

Tabel 1 Estimasi Parameter pada Model Regresi Klasik

\begin{tabular}{lllll}
\hline Variabel & Koefisien & Std. error & t-stat & Prob. \\
\hline Konstanta & $-17070,0$ & 6799,0 & $-2,51$ & 0,0217 \\
$X_{1}$ & 108,6 & 1022,0 & 0,11 & 0,9165 \\
$X_{2}$ & 1651,0 & 458,7 & 3,60 & 0,0020 \\
$X_{3}$ & 586,8 & 642,6 & 0,91 & 0,3732 \\
$X_{4}$ & $-54,9$ & 38,2 & $-1,44$ & 0,1675 \\
$X_{5}$ & 224,1 & 486,2 & 4,61 & 0,0002 \\
\hline
\end{tabular}

Taraf signifikan $(\alpha)=0,05$

Berdasarkan tabel 1, hasil pengujian menunjukkan adanya variabel-variabel prediktor yang signifikan berpengaruh terhadap variabel respon. Dikatakan signifikan jika nilai $p$-value $<\alpha(0,05)$, dimana pada penelitian ini variabel yang siginifikan tersebut adalah pengeluaran perkapita $\left(X_{2}\right)$ dan jumlah penduduk miskin $\left(X_{5}\right)$. Sehingga diperoleh model persamaan regresi klasik yaitu:

$$
\begin{gathered}
y=\beta_{0}+\beta_{2} X_{2}+\beta_{5} X_{5} \\
y=-17070+1651 X_{2}+224,1 X_{5}
\end{gathered}
$$

Keterangan :

$y=$ angka putus sekolah anak usia wajib belajar

$X_{2}=$ pengeluaran per kapita

$X_{5}=$ jumlah penduduk miskin

\subsection{Matriks Pembobot}

Selanjutnya dilakukan matriks pembobot yang pada dasarnya merupakan matriks pembobot yang distandarisasi. Susunan matriks yang diperoleh adalah berukuran $24 \times 24$, dimana baris dan kolom menyatakan Kabupaten/Kota di Provinsi Sulawesi Selatan. Karena matriks pembobot tersebut merupakan matriks simetris dengan aturan bahwa diagonal utama selalu bernilai 0 , sehingga dilakukan standarisasi untuk mendapatkan jumlah baris masing-masing unit penelitian bernilai sama dengan 1 .

\subsection{Uji Lagrange Multiplier (LM)}

Lagrange Multiplier digunakan untuk mendeteksi dependensi spasial dengan lebh spesifik yaitu dengan dependensi dalam lag, error, atau keduanya (lag dan error). Apabila Lagrange Multiplier lag dan error tidak signifikan maka 
dapat disimpulkan bahwa tidak terjadi dependensi spasial baik pada lag maupun error. Uji dependensi spasial dilakukan pada pembobot queen contiguity. Hasil pengujian Lagrange Multiplier ditunjukkan pada tabel 2.

Tabel 2 Hasil Uji Lagrange Multiplier

\begin{tabular}{lll}
\hline Uji Spatial Dependence & Nilai & p-value \\
\hline Lagrange Multiplier (lag) & 5,6020 & 0,0179 \\
Lagrange Multiplier (error) & 7,1800 & 0,0273 \\
Lagrange Multiplier (SARMA) & 7,5751 & 0,0226 \\
\hline
\end{tabular}

Berdasarkan tabel 2 diketahui bahwa nilai p-value dari LMerr, LMlag, dan SARMA signifikan karena lebih kecil dari $\alpha=0,05$ sehingga kita dapat menggunakan model SAR, SEM dan SARMA.

\subsection{Spatial Autoregressive (SAR)}

Analisis selanjutnya adalah memodelkan faktor-faktor yang mempengaruhi angka putus sekolah anak usia wajib belajar menggunakan model SAR. Hasil analisis tersebut diperoleh dengan menggunkaan program R. Hasil lebih lengkapnya dapat dilihat pada lampiran validasi running program. Hasil estimasi parameter pada model SAR disajikan pada tabel 4.3.

Tabel 3 Estimasi Parameter pada Model SAR

\begin{tabular}{lllll}
\hline Variabel & Koefisien & Std. error & t-stat & Prob. \\
\hline Konstanta & $-22477,0$ & 5425,0 & $-4,14$ & 0,0342 \\
$X_{1}$ & 698,5 & 790,3 & 0,88 & 0,3767 \\
$X_{2}$ & 1491,2 & 345,9 & 4,31 & 0,0162 \\
$X_{3}$ & 657,5 & 478,7 & 1,37 & 0,1695 \\
$X_{4}$ & $-64,8$ & 28,7 & $-2,26$ & 0,0237 \\
$X_{5}$ & 2137,2 & 363,5 & 5,88 & 0,0001 \\
$\rho$ & 0,4 & 0,2 & 6,07 & 0,0137 \\
\hline
\end{tabular}

Taraf signifikan $(\alpha)=0,05$

Berdasarkan tabel 3, hasil pengujian menunjukkan adanya variabel-variabel prediktor yang signifikan berpengaruh terhadap variabel respon. Dikatakan signifikan jika nilai $p$-value $<\alpha(0,05)$, dimana pada penilitian ini variabel yang siginifikan tersebut adalah pengeluaran perkapita $\left(X_{2}\right)$, rasio murid terhadap sekolah $\left(X_{4}\right)$ dan jumlah penduduk miskin $\left(X_{5}\right)$. Sehingga diperoleh persamaan model SAR yaitu:

$$
\begin{gathered}
\boldsymbol{y}=\rho \boldsymbol{W} y+\boldsymbol{X} \boldsymbol{\beta}+\boldsymbol{\varepsilon} \\
\varepsilon \sim N\left(0, \sigma^{2} I\right)
\end{gathered}
$$

Untuk, $\beta_{2}=1491,2, \beta_{4}=-64,8, \beta_{5}=2137,2, \rho=0,4$

Sehingga:

$$
y_{i j}=0,4 \sum_{j=1, i=1}^{24} W_{i j} y_{i}+1491,2 X_{2}-64,8 X_{4}+2137,2 X_{5}
$$

Keterangan :

$$
\begin{aligned}
y_{i j} & =\text { agka putus sekolah anak usia wajib belajar } \\
X_{2} & =\text { pengeluaran per kapita } \\
X_{4} & =\text { rasio murid terhadap sekolah } \\
X_{5} & =\text { jumlah penduduk miskin } \\
W_{i j} & =\text { matriks pembobot spasial }
\end{aligned}
$$




\section{Kesimpulan}

Berdasarkan hasil dan pembahasan mengenai aplikasi regresi spasial untuk pemodelan angka putus sekolah di Provinsi Sulawesi Selatan, maka diperoleh kesimpulan yaitu:

1. Pada hasil analisis regresi klasik diperoleh bahwa pengeluaran perkapita $\left(X_{2}\right)$ dan jumlah penduduk miskin $\left(X_{5}\right)$ berpengaruh signifikan terhadap angka putus sekolah sedangkan rata-rata lama sekolah $\left(X_{1}\right)$, rasio murid terhadap guru $\left(X_{3}\right)$ dan rasio murid terhadap sekolah $\left(X_{4}\right)$ tidak berpengaruh signifikan terhadap angka putus sekolah anak usia wajib belajar di Provinsi Sulawesi Selatan pada tahun 2018. Sedangkan hasil analisis regresi spasial dengan menggunakan model SAR diperoleh bahwa pengeluaran perkapita $\left(X_{2}\right)$, rasio murid terhadap sekolah $\left(X_{4}\right)$ dan jumlah penduduk miskin $\left(X_{5}\right)$ berpengaruh signifikan terhadap angka putus sekolah sedangkan rata-rata lama sekolah $\left(X_{1}\right)$ dan rasio murid terhadap guru $\left(X_{3}\right)$ tidak berpengaruh signifikan angka putus sekolah anak usia wajib belajar di Provinsi Sulawesi Selatan pada tahun 2018.

2. Dari model analisis regresi spasial dapat disimpulkan bahwa semakin besar pengeluaran per kapita $\left(X_{2}\right)$ maka semakin besar pula tingkat angka putus sekolah, dan semakin tinggi jumlah rasio murid terhadap sekolah $\left(X_{4}\right)$ maka semkin rendah angka putus sekolah, serta jika jumlah penduduk miskin $\left(X_{5}\right)$ semakin besar maka semakin besar pula tingkat angka putus sekolah.

\section{References}

Anselin, L. (1988). Spatial Econometrics: Methods and Models. Santa Barbara: Kluwer Academic Publshers.

Arif, A. (2018). Perbandingan Matriks Pembobot Spatial Optimum dalam Spatial Error Model (SEM) (Kasus : Indeks Pembangunan Manusia Kabupaten/Kota di Provinsi Sulawesi Selatan Tahun 2015). Makassar: Universitas Negeri Makassar.

Arisanti. (2011). Model Regresi Spasial untuk Deteksi Faktor-faktor Kemiskinan di Provinsi Jawa Timur. 44.

Fitroni, B. d. (2013). Pemodelan Angka Putus Sekolah Usia Wajib Belajar Menggunakan Metode Regresi Spasial di Jawa Timur. Sains dan Seni, 6.

Idris, Z. (2015). Pemodelan Kriminalitas dengan Pendekatan Regresi Spasial di provinsi Sulawesi Selatan. Makassar: Universitas Negeri Makassar.

Kurniawan, D. (2008). Regresi Linear (Linear regression). Forum Statistika.

LeSage, J. (2009). Introduction to Spatial Economitrics. USA: CRC Press, Taylor \& Francis Group.

Nasra. (2016). Pemodelan Angka Putus Sekolah Bagi anak Usia wajib Belajar di Provinsi Sulawesi Selatan dengan Pendekatan Generalized Poisson Regression (GPR). Makassar: Matematika FMIPA Universitas Negeri Makassar.

Nusrang, M., \& Annas, S. (2014). Outlier dalam Model Autoregresi Spasial (SAR). Makassar: Fakultas Matematika dan Ilmu Pengetahuan Alam Universitas Negeri Makassar.

Rizqa, N. (2015). Faktor Penyebab Anak Putus Sekolah pada Tingkat SMP di Desa Bimi Rejo Kecamatan Baradatu Kabupaten Way Kanan Tahun 2004. Lampung: Pendidikan Geografi Universitas Lampung.

Ruliana. (2015). Pemodelan Generalized Poisson Regression (GPR) untuk Mengatasi Pelanggaran Equidispersi pada Regresi Poisson Kasus Campak di Kota Semarang. Skripsi, 87.

Statistik, B. P. (2018). Statistik Daerah Provinsi sulawesi Selatan 2018. Makassar: Badan Pusat statistik Kota Makassar. 